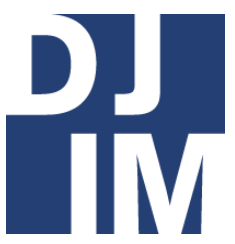

Volume 13

Spring

2017

djim.management.dal.ca |

\title{
Genetic Discrimination: Information Privacy in Public and Private Sectors
}

Colleen Faulkner

School of Information Management, Dalhousie University

\begin{abstract}
Deoxyribonucleic acid (DNA), is the information of life. The scientific understanding of genetics and biotechnology has resulted in the increased availability and affordability of genetic testing. Such testing can provide valuable information to help individuals make informed decisions regarding their lifestyle and health care. If such information finds itself in the wrong hands, there can be consequences such as genetic discrimination. Genetic discrimination, the unfair treatment of people due to their genetic makeup, often takes place in the insurance industry and by employers. While there are acts and bills to protect Canadians' personal information in both the public and private sector, Canada remains the only G-7 country without specific protections against genetic discrimination. With the recent passing in the Senate of Bill S-201: An Act to Prohibit and Prevent Genetic Discrimination, Canada is on the cusp of passing legislation to prohibit the requirement for genetic testing, and/or disclosure of test results, in the provision of insurance and employment.
\end{abstract}

\section{Introduction}

The understanding of genetics and biotechnology has come a long way since Watson and Crick's discovery of DNA in 1953 (The Tech Museum of Innovation, 2013). Genetic sequencing has become The understanding of genetics and biotechnology has come a long way since Watson and Crick's discovery of DNA in 1953 (The Tech Museum of Innovation, 2013). Genetic sequencing has become cheaper, quicker, and more accessible to the general public. Individual genome sequencing promises to provide 'the next big thing' in medical care personalized medicine, which is the provision of "the right medicine to the right person at the right dose and at the right time" (Ontario Genomics, n.d., para. 1). This will help provide optimum medical treatment to individuals based on their DNA.

In medical settings today, genetic screening is more common, and is used to help detect 
problems in genes, chromosomes, or proteins, even before a baby is born (National Library of Medicine [NLM], 2016c). While genetic testing is voluntary, it can provide valuable information to help individuals make decisions regarding their lifestyle and health care. As will be explored in this review paper, not only do individuals have a personal right to decide if they want to undergo genetic sequencing/testing, they should also have a right to privacy through control over who can access such information.

This review paper will look at: the importance of privacy, both in general and with respect to health information; the notion that genetic information may warrant special protections over and above general health information; and whether there are any protections in place to help prevent the misuse of health and genetic information in the public and private sectors, with a special emphasis on the insurance industry.

\section{Terminology}

For the purposes of this paper, there are distinctions made between the terms "security", "confidentiality", and "privacy" with regards to information. "Security" refers to the practice of ensuring that information remains confidential and private, by the adoption of data and information safeguards, such as locks and digital security measures. "Privacy" relates to a person's right to control the use of their information, whereas "confidentiality" speaks to the responsibility that professionals have to maintain this privacy when information is disclosed to them (Prosser, 2000).

Similarly, there is a difference between the concepts of access to information and disclosure of information. "Access" refers to an individual's right to obtain information about themselves or the government, whereas "disclosure" refers to the dissemination of information to a third party, such as another individual, organization, or government (Prosser, 2000).

\section{The Concept of Privacy and the Canadian Context}

\section{The Right to Be Let Alone}

Warren and Brandis (1890) first highlighted the issue of personal privacy, or the right to be let alone, after the invention of the camera. Over the years, the ease of dissemination of information via information and communication technologies has further increased the relevance that the right to privacy plays in society. This right is recognized internationally through the Universal Declaration of Human Rights, to which Canada is a signatory (U nited Nations Educational, Scientific and Cultural Organization,1997), and as a constitutional right in Canada, as outlined in Sections 7 and 8 of the Canadian Charter of Rights and Freedoms (Government of Canada, 1982; LaForest, 2005; Prosser, 2000).

In Canada, the expansion of government services after World W ar II, and the resulting increase in the amount of collected information, necessitated the development of privacy legislation (LaForest, 2005). In the late 1960s, some provinces began to implement such legislation, and by the early 1970s, the federal government had as well (LaForest, 2005). In 1983, the federal offices of the Information Commissioner and P rivacy Commissioner were established, followed two years later by the institution of a bill containing the Access to Information Act and P rivacy Act (see section "General Privacy Legislation in Canada”) (LaForest, 2005; 
Office of the Privacy Commissioner of Canada [OPC ], 2014). In 1988, the Supreme Court of Canada extended the definition of privacy to include informational privacy (R. v. Dyment, 1988), which Westin defines as "the claim of individuals, groups, or institutions to determine for themselves when, how, and to what extent information about them is communicated to others" (as cited in Prosser, 2000, p. 7).

\section{General Privacy Legislation in Canada}

While the purpose of this paper is not to engage in legal discourse, a highlight of the general privacy legislation in Canada follows. The Access to Information Act and Privacy Act provides individuals with the right to access information held by the federal government about the government and themselves, respectively (Government of Canada, 2016; LaForest, 2005). The Privacy Act also provides regulations regarding the collection, use, and disclosure of personal information within the federal government including name, age, ethnicity, fingerprints, blood type, and medical history (G overnment of Canada, 2016; LaForest, 2005). In Nova Scotia, the Freedom of Information and Protection of Privacy Act, or FOIPOP, provides privacy protection for information held within provincial government bodies (Province of Nova Scotia, 2008). From a private sector perspective, in 2000 parliament enacted the Personal Information Protection and Electronic Documents Act (Bill C-6, PIPEDA) in response to privacy concerns heavily influenced by the ubiquity of the Internet (LaForest, 2005; Prosser, 2000). As will be seen in the next section, the protection of health-related information, which is often viewed as more sensitive in nature than other personal information, may not be adequately protected under the above acts (Prosser, 2000; Canada Health Infoway, 2016).

\section{Health Information Privacy in Canada}

While personal health information still exists in paper formats, Gheorghiu and Hagens (2016) report that, in 2015, around 250,000 Canadian health professionals, or half of the total anticipated users, had used or accessed electronic health information. Many Canadians support the adoption of Electronic Health Records (EHRs) and the accessibility to vital information it provides. One study found that $56 \%$ of participants agreed that concerns about privacy and security were outweighed by the convenience of EHRS and the ability to have access to their information online (Canada Health Infoway, 2016). Electronic records present additional safety and security challenges over traditional paper files, and safeguards must be implemented to adequately protect them.

As a follow-up to its previous iteration, the 2012 Electronic Health Information and P rivacy Survey, surveyed 2,509 Canadians aged 16 and over by phone to determine their views on health information privacy in today's digital age (Canada Health Infoway, 2012). Sixty percent felt that "there are few types of personal information that are more important for privacy laws to protect than personal health information" (Canada Health Infoway, 2012, p. 10), despite only 52\% being aware of such laws. Support for EHRs was high, and eight out of ten respondents perceived that their information was at least moderately safe and secure (Canada Health Infoway, 2012). It is interesting to note the large discrepancy in the amount of trust Canadians reported regarding which entities could access their information. Only 37\% said they trusted medical or health insurance companies with this access, whereas $83 \%$ 
stated that they trusted family physicians (Canada Health Infoway, 2012). This distrust of medical or health insurance companies may indicate a necessity for more stringent legislation regarding the access to, and use of, health information by this industry.

The Advisory Council on Health Infostructure (1999) has recommended that governments institute transparent protection policies to protect personal health information, including information related to patients' integrity, autonomy, and identity. The Canadian Institute for Health Information, a nongovernmental organization, has developed guidelines for the management of a health information infrastructure with its Health Information Roadmap (Prosser, 2000).

\section{Health Information Privacy Legislation in Canadian Provinces}

Hospitals and other care facilities fall under the control of provincial legislation, in addition to health professionals' codes of ethics and conduct, such as the Hippocratic Oath and the Canadian Medical Association's Principles for the Protection of Patients' Personal Health Information Privacy policy (Canadian Medical Association, 2011). In general, when health information is to be used for what is known as a "primary purpose", such as further health care services, explicit consent may not be required for disclosure (Prosser, 2000). This is also the case in certain legal or public health and safety-related circumstances, like the reporting of communicable diseases (Prosser, 2000).

At the provincial level, Manitoba was first to pass legislation in 1997 with its Personal Health Information Act (PHIA), followed two years later by the Health Information Act (HIA; Bill 40) in Alberta, and the Health
Information Protection Act (HIPA) in Saskatchewan (Prosser, 2000). Nova Scotia's, Bill 89: Nova Scotia Personal Health Information Act (NSPIHA) took effect in 2013 (Department of Health and Wellness [DHW ], 2014).

Similar to PIPEDA, NSPIHA protects both analog and digital health information collected about Nova Scotians through the health sector (DHW, n.d.). The information that is accessed by the Department is collected through various custodians such as provincial care programs like Senior's Pharmacare, and both health authorities (Izaak Walton Killam Health Centre (IWK) and Nova Scotia Health Authority). This includes access to the provinces' EHR system - SHAR e (Electronic Secure Health Access Record) (DHW, n.d.). Under the NSPIHA, Nova Scotians have a right to: access their personal health information, be aware of who collects it, how it is used, request for non-disclosure of information in certain circumstances, be notified in the case of stolen or lost information, and make any relevant complaints to the DHW P rivacy and Access Office (DHW, 2014).

\section{Genetic Information use and Privacy}

Genetic information is a very specific form of personal health information, which is currently not explicitly mentioned in any general privacy legislation in Canada. Deoxyribonucleic acid (DNA) is the information of life; errors in DNA base pairs can lead to gene mutations, which can result in the occurrence of, or predisposition to, diseases such as sickle cell anemia, breast cancer, Huntington's, and cystic fibrosis (NLM, 2016a). Advances in medical science have allowed for the detection of such genetic diseases or predispositions through genetic testing. 


\section{Genetic Testing}

With over 1000 different tests currently available, genetic testing allows for the discovery of changes in genes, chromosomes, or resulting proteins (NLM, 2016a). Results of tests can be diagnostic, provide information on carrier status, or may indicate whether someone is likely to develop a disorder later in life (known as predictive or presymptomatic testing) (NLM, 2016a). Genetic testing is becoming part of regular health care. For example, the Maritime Newborn Screening Program delivered through the IWK Health Centre in Halifax, Nova S cotia, currently provides screening for 15 genetic conditions for babies born in Nova Scotia, New Brunswick, and Prince Edward Island (IWK Health Centre, 2016). The aim is to provide early diagnosis and treatment to help improve overall health and wellbeing in these infants and the greater population (IWK Health Centre, 2016).

Until recently, testing was only available through health care providers. However, over the past decade, companies such as 23andMe and EasyDNA have started to provide direct-to-consumer genetic testing, allowing people to discover information contained in their DNA (23andMe, Inc., 2016a; 23andMe, Inc., 2016b; EasyDNA, 2016). 23andMe states that people should have control over their personal information and how it is shared, and warns potential customers that insurance companies or employers may request genetic information if someone has a genetic test (23andMe, Inc., 2016a; 23andMe, Inc., 2016b). Their Privacy Highlights indicate that information they collect can be used for the improvement of services, in cases permitted by laws and regulations, and in marketing and advertising (23andMe, Inc., 2016b). It also specifies, that sensitive information won't be used without consent unless it is anonymized, used in aggregate form, or is required by courts (23andMe, Inc., 2016b). A survey of the EasyDNA website does not show such privacy details, nor warnings about the potential use of genetic test results by insurance companies or employers (EasyDNA, 2016).

Having access to genetic information is a personal choice that can empower people to take a more active role in their health care and lifestyle choices. Understanding the nuances of genetic testing, especially predictive or presymptomatic testing, is extremely complicated. In the case of multifactorial diseases such as cancer, the presence or absence of genetic markers for a disease does not automatically mean a person will or will not develop it (Human Genetics Society of Australia, 2017). As such, direct-to-consumer genetic testing may not provide the necessary information for consumers to make fully autonomous and informed decisions - especially if making significant health care or lifestyle changes (NLM, 2017). These changes could include undergoing a preventive mastectomy, as undertaken by Angelina J olie in 2013, upon discovering she was a carrier of the BRCA1 gene, which increased her risk of developing breast cancer to $87 \%$ (Griffith-Greene, 2015). W ithout adequate, counselling about the results of genetic tests, as would be the case in a clinical setting, consumers may not be able to make the best decisions with the information they receive. There is also a risk of disclosure of personal health information with direct-to-consumer testing, since private companies may not be required to adhere to as stringent privacy guidelines as the health care sector.

\section{Genetic Discrimination}


In some scenarios, knowledge of genetic information can lead to genetic discrimination - the unfair treatment of people due to "actual or perceived differences in their genetic information that may cause or increase the risk to develop a disorder or disease" (Canadian Coalition for Genetic Fairness, 2015, para. 3) - which often takes place in the insurance industry and by employers (Canadian Coalition for Genetic Fairness, 2015). Tim Caufield (2015), a columnist with Policy Options and Canada Research Chair in Health Law and Policy at the University of Alberta, argues that public fear regarding genetic discrimination may be somewhat unfounded and propagated by the media. Joly, Ngueng Feze, and Simar's (2013) systematic review of 33 studies found that $42 \%$ concluded that genetic discrimination existed and "gave grounds for serious concern" (p. 11), 48\% found the incidences of genetic discrimination were rare, and $9 \%$ found no evidence. The researchers noted that there were methodological limitations in reviewed studies preventing a full assessment of the impact of genetic discrimination (J oly, Ngueng Feze \& Simar, 2013). This inability to assess impact is also noted by the Canadian Coalition for Genetic Fairness (2015) which states, that even though this form of discrimination is real, exact numbers are hard to determine. Regardless of whether or not genetic discrimination is occurring in reality, a fear of genetic discrimination can, nonetheless impact an individual's decision to fully participate in health care, as well as research studies aimed at the public good, if genetic tests are required, (Canadian Coalition for Genetic Fairness, 2015; National Human Genome Research Institute, 2016). Since everyone has the potential to have multiple gene mutations, the issue of genetic discrimination can impact anyone. There is a strong need for legislative protection against this form of discrimination.

\section{Genetic Discrimination and the Insurance Industry}

The private insurance industry plays a large role in today's marketplace, as the availability of certain private health care services, such as physiotherapy, vision, and dental care, is increasing (Genetic Alliance, n.d.). The Canadian Life and Health Insurance Association (CLHIA) represents 99\% of Canada's life and health insurance business (CLHIA, 2016b). CLHIA (2016a) indicated that in 2015 the insurance industry protected over 28 million Canadians. The premise of insurance is based on the concept of risksharing - insureds who have a similar level of personal risk combine financial assets in a pool of money to be used in cases of unexpected events (Adjin-Tettey, 2013). Individuals who are deemed to have a lowrisk profile are considered "standard" and rarely denied coverage, whereas those in a higher risk "substandard" category are either charged higher premiums or denied coverage altogether (Adjin-Tettey, 2013). In determining someone's risk, companies engage in "actuarial discrimination" requesting individuals to divulge personal health information about themselves and their family members for the underwriting process (Adjin-Tettey, 2013). Insurers deem this information necessary to prevent the absorption of unreasonably high risks, which may lead to an increase in premiums for all insureds. However, a proverbial 'catch-22' often results: those who are at a higher medical risk may need health and life insurance more than those at low risk, but may end up being denied coverage due to said risk. 
The CLHIA states that, "insurers will not initiate or require any applicant to undergo a genetic test as part of the process of applying for insurance" (CLHIA, n.d., p. 1), however, individuals who are aware of their genetic information have a duty to disclose as part of the 'moral obligations' associated with an insurance contract (Adjin-Tettey, 2013; Griffith-Green, 2015). This information will potentially be used to determine insurability (CLHIA, n.d.). While an individual may think that their personal privacy is protected under a provision of 'don't ask, don't tell', a breach of contract may result if their information becomes known to the company, especially in the case of positive presymptomatic testing, and will result in a void policy (AdjinTettey, 2013; Spears, 2014).

The question now presents itself: should genetic information be treated differently, or afforded more privacy protection, than other health information used by the insurance industry? Insurance companies are generally against this notion of "genetic exceptionalism", arguing that the use of genetic information for underwriting purposes is no different than the use of blood work or another diagnostic test (Adjin-Tettey, 2013). Insurers argue that ignoring genetic results may unduly burden the insurance industry, forcing low-risk insureds to pay for those considered at a substandard risk (Adjin-Tettey, 2013).

Conversely, Adjin-Tettey (2013) explored the issue of genetic exceptionalism in depth, and provide various reasons why the treatment of genetic information may warrant special protections. Firstly, genetic information is unique in that it can provide knowledge that may impact not only an individual, but their family, and perhaps even community. The selective coverage of people due to their DNA could therefore lead to a form of racial discrimination. For example, sickle cell anemia and Tay-Sachs disease, are seen more often in African and Ashkezani J ewish populations, respectively (Adjin-Tettey, 2013).

Secondly, whether someone wants to obtain information about their genetic makeup is a personal decision and should not be made in the context of insurance-related issues. A 2003 study of 1,224 Canadians from ten provinces found that $90 \%$ of participants felt that insurance companies do not have a right to use or access their genetic information (Pollara Earnscliffe, 2003). Insurance may be required to participate fully in some aspects of life, such as owning a business and obtaining a mortgage (Adjin-Tettey, 2013). Denying people insurance due to genetic differences beyond their control can therefore lead to the development of a "genetic underclass" comprised of people who do not have the same privileges in society, due to their genetic makeup (AdjinTettey, 2013).

Lastly, as mentioned previously, a fear of negative consequences may discourage people from obtaining testing necessary to help improve their health, and the health of others through participation in research.

\section{Protections against Genetic Discrimination}

From an international perspective, the 1993 Declaration of Bilbao, UNESCO's 1997 Universal Declaration on the Human Genome and Human Rights, UNESCO's 2003 International Declaration on Human and Genetic Data, and the 2004 United Nations Economic and Social Council's Resolution 2004/09 on Genetic Privacy and Non-Discrimination all oppose the use of personal genetic (and sometimes proteomic) 
information and data as a means of discrimination (Canadian Coalition for Genetic Fairness, 2015). Different legislative methods have been used in various countries to protect against the use of genetic information by insurance companies. For example, Austria, Belgium, Norway, and France have instituted bans on the use of genetic information for underwriting (AdjinTettey, 2013). Whereas, Germany has a twotier system in which insurance agencies cannot exclude anyone from obtaining insurance due to personal risk factors, but can offer a "luxury" policy which requires the use of genetic information (Adjin-Tettey, 2013).

In 2008 and 2009, the Genetic Information Non-Discrimination Act (GINA) came into force in the United States (National Human Genome Research Institute, 2016). Title I of GINA protects against discrimination to obtaining health insurance, while Title II provides workplace related protections. Title I, of the Act further specifies that genetic information cannot be used to determine if a person is eligible for health insurance, including underwriting decisions (National Human Genome Research Institute, 2016). To this end, companies cannot specifically ask for genetic testing or ask for the provision of genetic information (National Human Genome Research Institute, 2016). It should be noted that GINA does not provide protections for other types of insurance, such as life or disability (Genetic Alliance, n.d.). In addition, it does not protect people who already have a "manifest disease", rather it only applies to those with predispositions for conditions to emerge later in life (United States, 2008; United States Department of Labour, 2009).

In Canada, the Canadian Charter of Rights and Freedoms and the Canadian Human
Rights Act provide protections and freedoms against discrimination due to factors such as age, gender, color, sex, and disability (Government of Canada, 1982; Government of Canada, 1985). The Canadian Human Rights Act specifies that a discriminatory practice includes the denial of a good or service, including employment, but does not specify the provision of insurance (Government of Canada, 1985, c. 33, s. 5). As previously described, the Privacy Act and Access to Information Act provide protections and rights for personal information held by the federal government. PIPEDA and its fair information principles apply to the private sector and is applicable to information obtained from companies providing direct-to-consumer genetic tests (OPC, 2017). Within the provincial health care systems, different provinces have enacted different legislation for protecting health information, such as the Personal Health Information Act in NS. With such a piecemeal approach to privacy legislation, there is the potential that some information may fall through the cracks.

In April 2016, a private members bill, Bill S201: An Act to Prohibit Genetic Discrimination, was passed by the Senate and is now at the House of Commons (Bill S201, 2016; MacLeod, 2016). Also known as the Genetic Non-Discrimination Act, this act, like GINA in the United States, specifically addresses the impact that genetic discrimination can have on the life of Canadians. Beyond the protections afforded by GINA, the Canadian bill, if adopted, would prohibit the use of genetic testing or the disclosure of test results in the provision of goods and services, especially with respect to health and life insurance, and employment (Bill S-201, 2016; MacLeod, 2016). Bill S-201 will also amend the Canada Labour Code 
and the Canada Human Rights Act to protect against discrimination based on genetics (Bill S-201, 2016). Despite not yet being passed, this act holds great promise for the protection of Canadians and their information, especially as pertains to their DNA.

\section{Conclusion}

This paper has investigated what privacy means, and how the privacy of personal and health information is vital to the health and wellbeing of not only individuals but the larger community and public good. While there are acts and bills to protect Canadians personal information in both the public and private sectors, Canada remains the only $\mathrm{G}$ 7 country without specific protections against genetic discrimination (Canadian Coalition for Genetic Fairness, 2015), though this is in the process of changing with Bill S-201.

Genetic discrimination can be seen in the underwriting practices of insurance companies, which routinely deny coverage due to personal and family health history. While insurers deem this discrimination necessary for the viability of the industry and to keep premiums reasonable for all insureds, critics suggest such actions may encourage the creation of an underclass of people unable to participate as fully in society as their more genetically fortunate peers (Adjin-Tettey, 2013). While persuasive arguments are found on both sides, the question remains: should society, and governments specifically, help to protect those at risk of genetic discrimination? W ith the passing of Bill S-201 in the Senate (Bill S-201, 2016), Canada is on the cusp of protecting those at risk by passing legislation to prohibit the requirement for genetic testing or disclosure of test results in the provision of insurance and employment.
From an information management perspective, issues of personal privacy are relevant with the increasing quantity of, and ease of access to, digitally-stored information. Information professionals responsible for the development of, or advisement on, such legislation play a vital role in balancing the interests of all stakeholders. For health-related information, most of which resides in the public sector, policies should be developed through the lens of the greatest public good. What is good for the public is not necessarily good for the private sector, as may be the case for the insurance industry if protection of personal genetic information is strengthened.

\section{References}

23andMe, Inc. (2016a). How it works. Retrieved from https://www.23andme.com/en ca/howitworks/

23andMe, Inc. (2016b). P rivacy highlights. Retrieved from https://www.23andme.com/enca/about/privacy/

Access to Information Act, R evised Statutes of Canada, 1985, c. A-1. Retrieved from http://lawslois.justice.gc.ca/P DF/A-1.pdf

Adjin-Tettey, E. (2013). Potential for genetic discrimination in access to insurance: Is there a dark side to increased availability of genetic information? Alberta Law Review, 50(3), 577-614.

Advisory Council on Health Infostructure. (1999). Paths to better health: Final report. Retrieved from 
http://dspace.ucalgary.ca/bitstream/1 880/43058/1/CHIpaths 1999.pdf

Bill 89: Personal Health Information Act. (2010). 61st General Assembly, 2nd Session. Halifax: Nova Scotia Legislature. Retrieved from http://nslegislature.ca/legc/bills/61st_ 2nd/3rd_read/b089.htm

Bill S-201: An Act to Prohibit and Prevent Genetic Discrimination. (2016). 42nd Parliament, 1st Session. Ottawa: Senate of $C$ anada. Retrieved from http://www.parl.gc.ca/HousePublicati ons/Publication.aspx? Language $=E \&$ Mode $=1 \&$ Docld $=8185825$

Canada Health Infoway. (2012). What Canadian's think: Electronic health information and privacy survey 2012. Retrieved from https://www.infowayinforoute.ca/en/component/edocman /resources/reports/privacy/461ipsos-reid-survey-on-electronichealth-information-and-privacy

Canada Health Infoway. (2016). Connecting patients for better health: 2016. Retrieved from https://www.infowayinforoute.ca/en/component/edocman /3152-connecting-patients-for-betterhealth-2016/view-

document? Itemid $=101$

Canadian Coalition for Genetic Fairness. (2015). About genetic discrimination. Retrieved from http://ccgfcceg.ca/en/about-geneticdiscrimination/

Canadian Life and Health Insurance Association. (2016a). Canadian life and health insurance facts, 2016 edition. Retrieved from https://www.clhia.ca/domino/html/clhi a/CLHIA_LP4W_LND_Webstation.n sf/483b14f0df72bb2a8525783b0072 662e/6b3ac3ea7f05bc6e8525802e0 06851eb!O penDocument

Canadian Life and Health Insurance Association. (n.d.). Industry code: Genetic testing information for insurance underwriting. Retrieved from https://www.clhia.ca/domino/html/clhi a/CLHIA_LP4W_LND_Webstation.n $\mathrm{sf} /$ resources/G uidelines/\$file/Industr $y_{-}$Code_Genetic_Testing.pdf

Retrieved from Canadian Life and Health Insurance Association. (2016b). Mission and objectives. Retrieved from https://www.clhia.ca/domino/html/clhi a/CLHIA_LP4W_LND_Webstation.n sf/page/6EBFE54D9D076C5685257 80E 0056B 1BE? O penDocument

Canadian Medical Association. (2011). $P$ rinciples for the protection of patients' personal health information. Retrieved from http://policybase.cma.ca/dbtwwpd/Policypdf/P D11-03.pdf

Caulfield, T. (2015, December 7). The cure - column. Policy O ptions. Retrieved from http://policyoptions.irpp.org/magazin es/december2015/geneticdiscrimination/

Department of Health and Wellness. (n.d.). Your personal health information and the Department of Health and Wellness. R etrieved from 
http://novascotia.ca/dhw/phia/privacy /DHW-Notice-of-Purposes.pdf

Department of Health and Wellness. (2014). Personal Health Information Act. Retrieved from http://novascotia.ca/dhw/phia/ EasyDNA. (2016). About us. Retrieved from https://www.easydna.ca/about-us/

Freedom of Information and P rotection of Privacy Act, Province of Nova Scotia, 1993, c. 5, s.1. Retrieved from http://nslegislature.ca/legc/statutes/fr eedom\%20of\%20information\%20an d\%20protection $\% 20$ of\%20privacy.pd $\mathrm{f}$

Genetic Alliance. (n.d.). Genetic discrimination. Retrieved from http://www.geneticalliance.org/advoc acy/policyissues/geneticdiscriminatio $\mathrm{n}$

Government of Canada. (1982). Canadian Charter of Rights and F reedoms. Retrieved from http://lawslois.justice.gc.ca/eng/const/page15.html

Government of Canada. (1985). Canadian Human Rights Act (R.S.C., 1985, C. $H-6)$. R etrieved from http://lawslois.justice.gc.ca/eng/acts/h-6/

Government of Canada. (2016). About the ATIP program. Retrieved from http://www.infosource.gc.ca/emp/em p01-eng.asp\#atip

G riffith-G reene, M. (2015, April 2). Home DNA tests may affect insurance, employment. CBC News. Retrieved from

http://www.cbc.ca/news/health/home -dna-tests-may-affect-insuranceemployment-1.3018086

Human Genetics Society of Australia. (2017). Guidelines: P re-symptomatic and predictive testing for genetic disorders. Retrieved from https://www.hgsa.org.au/documents/ item/1574

Izaak Walton Killam Health Centre. (2016). The Maritime newborn screening program. Retrieved from http://www.iwk.nshealth.ca/newborn screening

J oly, Y., Ngueng Feze, I., \& S imar, J . (2013). Genetic discrimination and life insurance: a systematic review of the evidence. BMC Medicine, 11:25. doi: 10.1186/1741-7015-11-25.

LaForest, G. V. (2005). The offices of the information and privacy commissioners: The merger and related issues. Retrieved from http://www.justice.gc.ca/eng/rppr/csj-sjc/atip-aiprp/ip/rep-rap.pdf

National Human Genome Research Institute. (2016). Genetic discrimination. R etrieved from https://www.genome.gov/10002077/

National Library of Medicine. (2016a). Help me understand genetics: Genetic testing. Retrieved from https://ghr.nlm.nih.gov/primer

National Library of Medicine. (2016b). What is a gene? Retrieved from 
https://ghr.nlm.nih.gov/primer/basics/ gene

National Library of Medicine. (2016c). What is genetic discrimination? Retrieved from https://ghr.nlm.nih.gov/primer/testing /discrimination

National Library of Medicine. (2017). What is direct-to-consumer genetic testing? Retrieved from https://ghr.nlm.nih.gov/primer/testing /directtoconsumer

MacLeod, I. (2016, February 18). Clash brewing over genetic privacy as insurance industry tries to get as much data as possible to assess risk. National Post. Retrieved from http://news.nationalpost.com/news/c anada/clash-brewing-over-geneticprivacy-as-insurance-industry-triesto-get-as-much-data-as-possible-toassess-risk

Office of the Privacy Commissioner of Canada. (2014). Overview of privacy legislation in Canada. Retrieved from https://www.priv.gc.ca/en/privacytopics/privacy-laws-incanada/02_05_d_15/

Office of the Privacy Commissioner of Canada. (2015). Privacy toolkit: A guide for businesses and organizations. Retrieved from https://www.priv.gc.ca/media/2038/g uide_org_e.pdf

Office of the Privacy Commissioner of Canada. (2017). Direct-to-consumer genetic testing and privacy.

Retrieved from https://www.priv.gc.ca/en/privacytopics/health-genetic-and-otherbody-information/02_05_d_69_gen/

Ontario Genomics. (n.d.). Ontario personalized medicine network. Retrieved from http://www.ontariogenomics.ca/impa ct/policy-impact/opmn

Pollara Earnscliffe. (2003). Public opinion research into genetic privacy issues. Ottawa: Pollara Research and Earnscliffe Research and Communications.

P rivacy Act, Revised Statutes of Canada, 1985, c. P-21. Retrieved from http://lawslois.justice.gc.ca/eng/acts/p-21/ Prosser, S. (2000). Personal health information and the right to privacy in Canada.

Retrieved from http://fipa.bc.ca/library/Reports_and_ Submissions/Personal_Health_Infor mation_and_the_Right_to_Privacy_i n_Canada-May_2000.pdf

Province of Nova Scotia. (2008).

Respecting your access and privacy rights: A citizen's guide for Nova Scotians. Retrieved from https://foipop.ns.ca/sites/default/files/ publications/Plain-LanguageGuide/FOIPOP-PLG.pdf

R. v. Dyment, 2 S.C.R. 417. (S upreme Court of Canada, 1988, December 8). Retrieved from http://scc- 
csc.lexum.com/scc-csc/scc-

csc/en/item/375/index.do

Spears, J. (2014, Sept. 25). Insurers won't demand genetic tests. The Star.

Retrieved from

https://www.thestar.com/business/pe

rsonal_finance/2014/09/25/insurers_

wont_demand_genetic_tests.html

The Tech Museum of Innovation. (2013).

What is a gene? Retrieved from

http://genetics.thetech.org/about-

genetics/what-gene

United Nations Educational, Scientific and Cultural Organization. (1997).

Universal Declaration on the Human Genome and Human Rights.

Retrieved from

http://portal.unesco.org/en/ev.phpUR

$L_{-} I D=13177 \& U R L_{-} D O=D O \_T O P I C$

$\& U R L \_S E C T I O N=201 . h t m l$

United States. (2008). The Genetic

Information Nondiscrimination Act of

2008 (GINA). Retrieved from

https://www.gpo.gov/fdsys/pkg/P LA

W-110publ233/html/P LAW -

110publ233.htm

United States Department of Labour.

(2009). The Genetic Information

Nondiscrimination Act of 2008

(GINA). Retrieved from

https://permanent.access.gpo.gov/g

po10163/fsgina.pdf

Warren, S. C., \& Brandeis, L. D. (1890). The right of privacy. Harvard Law

Review, 4, 193 - 195. 